Acta horticulturae et regiotecturae 1

Nitra, Slovaca Universitas Agriculturae Nitriae, 2013, s. 1-3

\title{
CHANGES IN VITAMIN C CONTENT AND SOLUBLE SOLIDS OF CARROT CONTENT (DAUCUS CAROTA L.) DURING STORAGE ZMENY V OBSAHU VITAMÍNU C A ROZPUSTNEJ SUŠINY MRKVY (DAUCUS CAROTA L.) POČAS SKLADOVANIA
}

\author{
Magdaléna VALŠÍKOVÁ, Miroslav ŠLOSÁR, ${ }^{1}$ Rudolf RYBAN, ${ }^{1}$ \\ Sami SHEHATA, ${ }^{2}$ Alžbeta HEGEDÜSOVÁ \\ Slovak University of Agriculture in Nitra, Slovak Republic ${ }^{1}$ \\ National Research Centre in Cairo, Egypt ${ }^{2}$
}

\begin{abstract}
The average vitamin C content of fresh carrots was $56 \mathrm{mg} \cdot \mathrm{kg}^{-1}$. Amount of vitamin C was reduced by the length of storage and storage environment. On average, the most significant decrease in vitamin C to $24.4 \mathrm{mg}^{\mathrm{kg}} \mathrm{kg}^{-1}$ under laboratory conditions was reported after 56 days when stored carrots were packed in plastic box. When stored in a refrigerator, the vitamin $C$ content decreased to 24.7 mg.kg-1 after 126 days of storage in a plastic box. During both experimental periods in laboratory conditions, the most vitamin $C$ was preserved while being wrapped plastic wrap. This way of packaging also enabled relatively long-term preservation of freshness in variety called "Komarno", which was up to 60 days. The second best option in this respect is the packed carrot in microtene bags. The least convenient was to store the carrots open without packaging. In the case of refrigerated storage, the options of packaging in plastic wrap and microtene bags were also the best. The most significant decline in vitamin $\mathrm{C}$ was found in the variant without packaging and in the food box. Average soluble solids (refractometry dry matter) content in fresh roots reached $7.6 \%$. During storage under laboratory conditions, the SS values increased to $14.8 \%$ after 14 days when the carrot was stored open without packaging. In the refrigerator, the soluble solids content in carrots increased to $12.7 \%$ after 28 days of storage without packaging. Increase in soluble solids content was mainly caused by transpiration process. Under laboratory conditions, evaporation and increase of soluble solids were faster compared to the variants stored in the cooler.
\end{abstract}

Keywords: carrot, storage, vitamin C, soluble solids

Slovakia produces annually about 300,000 tons of vegetables grown on arable land and in the gardens (Meravá a i., 2011). Group of root vegetables is one of the most important (Demo et al., 2001), in terms of consumerism and processing (Hrabě, Rop a Hoza, 2006). In Slovakia, the most cultivated from the above mentioned group are carrot, parsley, beetroot, celery and radish. Root vegetables are $17 \%$ of total vegetable production. In production and consumption, the root of carrot covers up to $70 \%$ of root vegetables (Valšíková a Ryban, 2012).

Carrot is easy to grow and well storable vegetable (Valšíková a Kopec, 2009). The shelf life of carrot quality ranges from 3 to 6 months at the temperature of -0.5 to $+1.5^{\circ} \mathrm{C}$, with humidity of 90 to $98 \%$ and optimum ventilation (Kopec a Valšíková 2002).

When the carrot crop is kept in cold storage, initially occurring polysaccharide decreases enhance its sweet taste. Later during the respiration, the carbohydrate content is reduced again. Edible part of carrot can have a slightly bitter taste due to the presence of sesquiterpenes in essential oils (Kopec, 2010).

\section{Material and methods}

The biological material of laboratory experiments included carrots grown in Botanic garden of Horticulture and Landscape Engineering Faculty in Nitra. The type of soil is medium - heavy to heavy. It contains 2.2 to $2.8 \%$ of humus and is capable of holding water and nutrients.
For experimental purpose we used 'Komarno' F1 variety of carrot originated in the United Kingdom. It is a medium late variety of carrots with vegetation period of 161 days. It has smooth roots with dark orange color. This variety is suitable for long-term storage and industrial processing as well.

Carrots were grown in 2009 and 2010. In both years they were planted at the end of April into rows with the distance of $0.60+0.15 \times 0.05 \mathrm{~m}$. The crop was mechanically treated during vegetation due to the removal of weeds and loosening of soil. No fertilizers were used during vegetation period.

The harvest of carrot roots was made 5. 10. 2009 and 7. 10.2010 and the samples were taken to the laboratory and walk-in cooler for conducting experiments. Experiments lasted from 2009 to 2011. On the day of harvest, we analyzed vitamin $C$ content in the carrot roots using titration method (Príbela, 1991). Measurement of soluble solids was made by Polish manufactoring refractometer PZO RK11, $122 \mathrm{NC}$ 01 , with a range of 0 to $30 \%$ at $20^{\circ} \mathrm{C}$. Further analyses were performed after storage (Plathyová a Valšíková, 2011).

\section{Variants of experiments:}

1. L-place of storage in the laboratory conditions:

- Carrots packed in food box (L-FB).

- Carrots packed in HDPE (microtene) bag (L-MB).

- Carrots packed in food foil (L-FF).

- Carrots on tray without packaging (L-WP).

2. R-place of storage in a refrigerator:

- Carrots packed in food box (R-FB).

- Carrots packed in HDPE (microtene) bag (R-MB). 
- Carrots packed in food foil (R-FF).

- Carrots stored on tray without packaging (R-WP).

During the storage under laboratory conditions, the average temperature was maintained at $20.7^{\circ} \mathrm{C}$, the average temperature of humidity was $51.3 \%$ in 2009-2010. In 2010-2011 it was $21.5^{\circ} \mathrm{C}$ and $50.2 \%$.

During the storage in refrigerator, the average temperature was $7.4^{\circ} \mathrm{C}$ and humidity over the 2009-2010 period was $44.2 \%$. In 2010-2011, the average temperature was $7.1^{\circ} \mathrm{C}$ and relative humidity of air $45.05 \%$.

\section{Results and discussion}

Average vitamin C content in fresh carrots was 56 mg. $\mathrm{kg}^{-1}$. Reduction of amount of vitamin C depended on the length of storage and storage conditions. Under laboratory conditions, the most significant decrease in vitamin $\mathrm{C}$ was detected. In average, it was up to $24.4 \mathrm{mg} \cdot \mathrm{kg}^{-1}$ after 56 days, when carrots were packed in food plastic box. When stored in refrigerator, content of vitamin C decreased up to $24.7 \mathrm{mg} \cdot \mathrm{kg}^{-1}$ after storage of 126 days and packed in food plastic box (Table 1).

According to author Kajaba, Šmrha, (1982), the average vitamin C content in edible part of carrot is $48 \mathrm{mg} \cdot \mathrm{kg}^{-1}$, which corresponds to our results. Kopec (1977) recommends storing carrots at the temperature of -0.5 to $+0.5{ }^{\circ} \mathrm{C}$ with relative humidity from 90 to $95 \%$. With optimum storage conditions, the losses are expected to reach up to $10 \%$ in three months. The losses represent between 15 to $50 \%$ with prolonged storage time to 6 months (Kopec a Valšíková, 2002).

The results obtained with measurements of refractometric dry matter (soluble solids) are given in table 2. We can conclude that average soluble solids content in fresh roots was $7.6 \%$. During storage under laboratory conditions, the soluble solids values increased to $14.8 \%$ after 14 days of open storage without packaging. In the refrigerator, the average content of soluble solids increased to $12.7 \%$ after 28 days of storage without packing.

An increase in water loss through the process of evaporation during storage causes increases in soluble solids content in carrots (Woods, 1990). Amount of evaporated water from the weight unit of crop per unit of time $\left(\mathrm{mg} \cdot \mathrm{k}^{-1} \cdot \mathrm{h}^{-1}\right)$ is the ratio of evaporation at humidity deficit of air ( $1 \mathrm{~g}$ to $1 \mathrm{~kg} \mathrm{H}_{2} \mathrm{O}$ ) which determines the intensity of wilting (Valšíková a Kopec, 1999). In our experiments the wilt intensity was strongest in both variants of experiments, when carrot roots were stored without packaging and weakest when the roots were wrapped in plastic wrap.

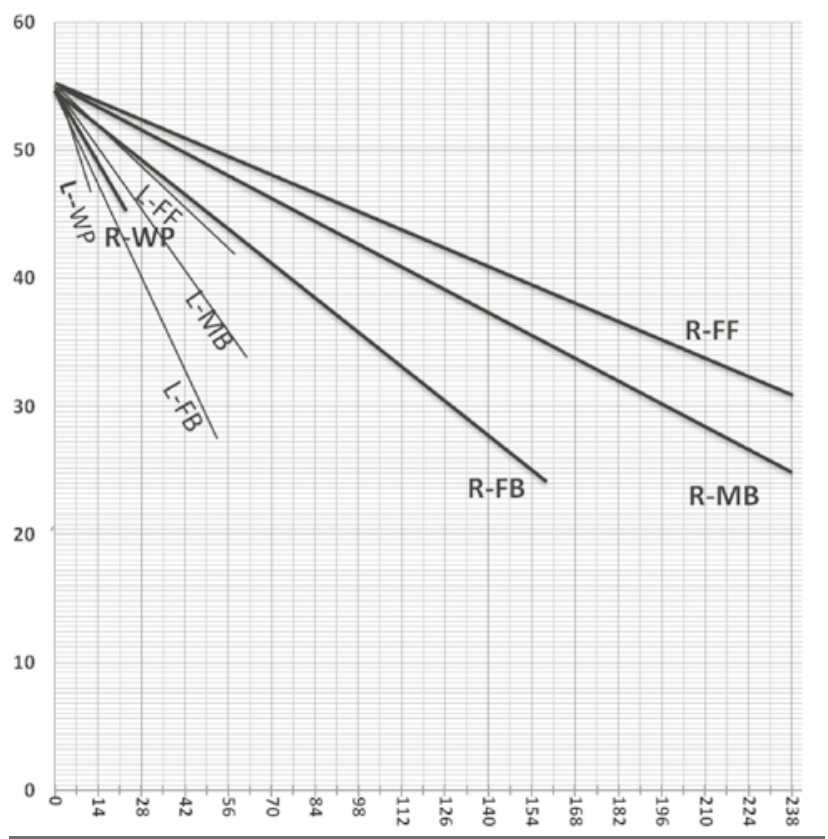

Figure 1 Decrease in vitamin C content during storage of carrot roots

Obrázok 1 Pokles vitamínu C v koreňoch mrkvy počas skladovania

Quality of packing significantly affects the duration of the shelf-life of carrots (Ayhan, Esiturk and Tas, 2008).

Decrease in vitamin $C$ and increase in soluble solids content during storage is shown in figure 1 and 2 . Figure 1 shows that under laboratory conditions, the highest value of vitamin $C$ has been preserved in carrots wrapped in plastic wrap (FF) during both experiment periods. This packaging also enabled relatively long-term preservation of freshness in variety called "Komarno", which was up to 60 days. The second best possibility of storage in this way was to pack carrots in microtene bags. The worst option proved to be open storage under natural conditions without package.

In refrigerated storage, the best way of storing was also wrapping the carrots in the plastic wrap (FF) and in plastic bags (MB). The most evident decrease in vitamin $C$ was in the variant without packaging or storage in plastic box ('FB).

Figure 2 shows an example of the increase in soluble solids content during storage of variety 'Komarno'. This increase was caused mainly by the transpiration process. Under laboratory conditions, the increases of evaporation and content of refractometric dry matter were faster compared to the case of carrots stored in a cooler.

Table 1 Average vitamin C content in the carrot root during storage in $\mathrm{mg}^{\mathrm{kg}} \mathrm{kg}^{-1}$

\begin{tabular}{|l|c|c|c|c|c|}
\hline Variety (1) & Before storage (2) & After storage (3) \\
\hline & Fresh carrots (F) (4) & Food box (FB) (5) & Microten bags (MB) (6) & Plastic wrap (FF) (7) & Without Packing (WP) (8) \\
\hline \multicolumn{7}{|c|}{ Storage under laboratory conditions (L) (9) } \\
\hline Komárno & $\mathbf{5 6}$ (0 days) & $\mathbf{2 4 . 4}$ (after 56 days) & $\mathbf{3 3 . 1}$ (after 67 days) & $\mathbf{4 2 . 1}$ (after 60 days) & $\mathbf{4 6 . 0}$ (after 14 days) \\
\hline \multicolumn{7}{|c|}{ Storage in refrigerator (R) (10) } \\
\hline Komárno & $\mathbf{5 6}$ (0 days) & $\mathbf{2 4 . 7}$ (after 126 days) & $\mathbf{2 6 . 4}$ (after 239 days) & $\mathbf{3 1 . 6}$ (after 239 days) & $\mathbf{4 3 . 2}$ (after 28 days) \\
\hline
\end{tabular}

Tabulka 1 Obsah vitamínu C v koreňoch mrkvy pri skladovaní v mg.kg-1

(1) odroda, (2) pred uskladnením, (3) po uskladnení, (4) čerstvé mrky, (5) krabica na jedlo, (6) mikroténové vrecko, (7) plastový obal, (8) bez balenia, (9) skladovacie a laboratórne podmienky, (10) uskladnenie $v$ chladničke 
Table 2

Average refractometric dry matter content in carrot roots during storage in \%

\begin{tabular}{|l||c|c|c|c|c|}
\hline \multirow{2}{*}{ Variety (1) } & Before storage (2) & \multicolumn{4}{|c|}{ After storage (3) } \\
\cline { 2 - 6 } & Fresh carrots (F) (4) & Food box (FB) (5) & Microten bags (MB) (6) & Plastic wrap (FF) (7) & Without Packing (WP) (8) \\
\hline \hline \multicolumn{5}{|c|}{ Storage under laboratory conditions (L) (9) } \\
\hline Komárno & $\mathbf{7 . 6}$ (0 days) & $\mathbf{1 2 . 1}$ (after 56 days) & $\mathbf{1 0 . 6}$ (after 67 days) & $\mathbf{8 . 5}$ (after 60 days) & $\mathbf{1 4 . 8}$ (after 14 days) \\
\hline \multicolumn{7}{|c|}{ Storage in refrigerator (R) (10) } \\
\hline Komárno & $\mathbf{7 . 6}$ (0 days) & $\mathbf{1 0 . 5}$ (after 126 days) & $\mathbf{1 1 . 2 ~ ( a f t e r ~ 2 3 9 ~ d a y s ) ~}$ & $\mathbf{1 0 . 1}$ (after 239 days) & $\mathbf{1 2 . 7}$ (after 28 days) \\
\hline
\end{tabular}

Tabulka 2 Obsah refraktometrickej sušiny v koreňoch mrkvy pri skladovaní v \%

(1) odroda, (2) pred uskladnením, (3) po uskladnení, (4) čerstvé mrky, (5) krabica na jedlo, (6) mikroténové vrecko, (7) plastový obal, (8) bez balenia, (9) skladovacie a laboratórne podmienky, (10) uskladnenie v chladničke

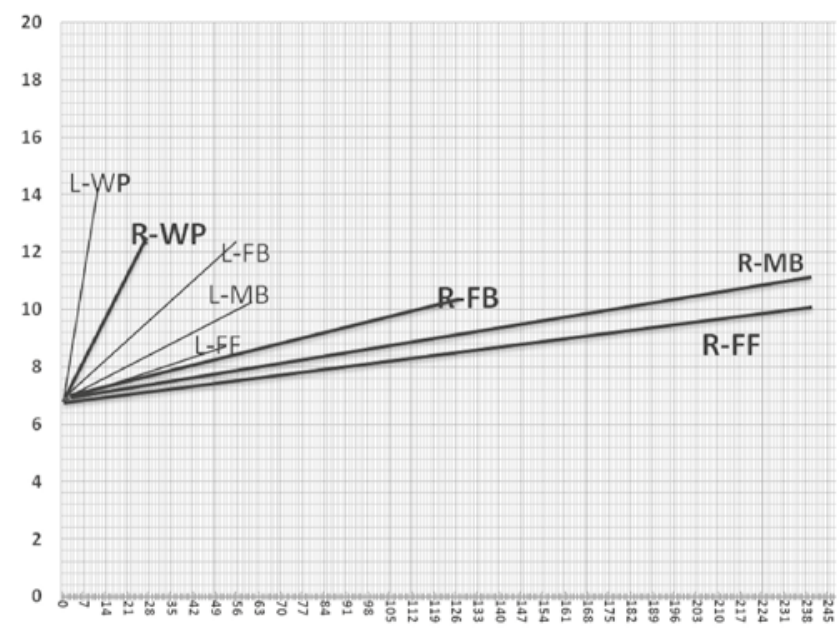

Figure 2 Increase in soluble solids content during storage of carrot roots

Obrázok 2 Zvýšenie obsahu rozpustnej sušiny v koreňoch mrkvy počas skladovania

\section{Súhrn}

Výsledky našich experimentov potvrdili, že priemerný obsah vitamínu C v čerstvej mrkve bol 56 mg.kg-1. Skladovaním sa množstvo vitamínu $C$ znižovalo podla dížky a podmienok skladovania. $\mathrm{V}$ laboratórnych podmienkach $\mathrm{v}$ priemere najvýraznejší pokles v množstve vitamínu $C$ na $24,4 \mathrm{mg} \mathrm{kg}^{-1}$ bol po 56. dňoch, ak sa mrkva skladovala zabalená do plastovej nádoby. Pri skladovaní v chladničke najviac klesol obsah vitamínu C na 24,7 mg. $\mathrm{kg}^{-1}$ po 126. dňoch skladovania v plastickej nádobe. V laboratórnych podmienkach najviac vitamínu $C$ sa v obidvoch pokusných obdobiach zachovalo pri variante balenia do potravinovej fólie. Toto balenie poskytlo súčasne aj relatívne dlhodobé uchovanie čerstvého stavu odrody 'Komarno' až 60 dní. Druhým najvýhodnejším variantom z tohto hladiska je balená mrkva do mikroténu. Najmenej výhodné bolo skladovanie $\mathrm{v}$ prirodzených podmienkach bez obalu. $\mathrm{V}$ prípade chladeného prostredia boli tiež najvýhodnejšie balenia do potravinovej fólie a mikroténových vrecúšok. Najvýraznejší pokles z hladiska obsahu vitamínu $C$ bol zaznamenaný pri variante bez obalu a v potravinovej krabici. Priemerný obsah refraktometrickej sušiny dosahoval $v$ čerstvých koreňoch $7,6 \%$. Počas skladovania v laboratórnych podmienkach sa hodnoty RS zvyšovali až do 14,8 \% už po 14. dňoch skladovania volne bez obalu. V chladničke sa obsah RS zvýšil na 12,7 \% po 28 dňoch pri variante skladovanom bez obalu. Počas skla- dovania mrkvy odrody 'Komarno' obsah RS stúpal. Bolo to spôsobené hlavne transpiračným procesom. V laboratórnych podmienkach boli vyparovanie a nárast RS rýchlejšie v porovnaní s variantmi skladovanými v chladiarenskom boxe.

Klúčové slová: mrkva, skladovanie, vitamín $C$, refraktometrická sušina

\section{References}

AYHAN, Z. - ESITURK, O. - TAS, E. 2008. Effect of Modified Atmosphere Packaging on the Quality and Shelf Life of Minimally Processed Carrots. In: Turk J. Agric. For, vol. 32, 2008, p. 57-64.

DEMO, M. a i. 2001. Dejiny pol'nohospodárstva na Slovensku. SPU v Nitre. Bratislava: VÚPaOP, 2001, 662 s. ISBN 80-7137-894-1.

HRABĚ, J. - ROP, O. - HOZA, I. 2006. Technologie výroby potravin rostlinného původu. Zlín: UTB, 2006, 178 s. ISBN 80-7318-372-2.

KAJABA, I. - ŠMRHA, O. 1982. Tabulky zloženia a výživových hodnôt požívatín. Bratislava : Slovenské pedagogické nakladatel'stvo, 1982, $103 \mathrm{~s}$. KOPEC, K. - VALŠÍKOVÁ, M. 2002. Starostlivost' o úrodu zeleniny. Nové zámky, 2002, 117 s. ISBN 80-968065-6-4.

KOPEC, K. 1977. Uskladňovanie záhradníckych plodín. Bratislava : Príroda, $317 \mathrm{~s}$.

KOPEC, K. 2010. Zelenina ve výživě člověka. Praha : Grada Publishing, a.s., 2010, 168 s. ISBN 978-247-2845-2.

Meravá, E. a i. 2011. Zelenina - Situačná a výhladová správa k 31. 12. 2010. Bratislava : VÚEPP, MPaRV SR, 2011, 54 s. ISBN 978-80-8058-562-4.

PLATTHYOVÁ, L. - VALŠíKOVÁ, M. 2011. Rozdiel v množstve a kvalite urody mrkvy pri pestovaní hrobčekovaním a tradičným spôsobom. In: Študentská vedecká konferencia FZKI 2011, Nitra : SPU, 2011, s. 69-76. ISBN 978-80-552-0676-9.

PRÍBELA, A. 1991. Analýza potravín. Bratislava : STU, 225 p. ISBN 80-227-0374-5.

UHER, A. - KÓŇA, J. - VALŠíKOVÁ, M. - ANDREJIOVÁ, A. 2009. Zeleninárstvo (pol'né pestovanie). Nitra, 2009, 212 s. ISBN 978-80-552-0199-3. VALŠ́́KOVÁ, M. - KOPEC, K. 1999. Zásady pozberovej úpravy a skladovania zeleniny. Nové Zámky: VÚZ, SZÚ, Bratislava :SPPK, 1999, 67 s. ISBN 80-968065-3-X.

VALŠíKOVÁ, M. - KOPEC, K. 2009. Pozberová technológia záhradníckych plodín. Nitra : SPU, 2009, 158 s. ISBN 978-80-552-0313-3. VALŠÍKOVÁ, M. - RYBAN, R. 2012. Produkcia mrkvy obyčajnej v SR. In: Zahradnictví, roč. 10, 2012, č. 5, s. 23-26. ISSN 1213-7596.

WOODS, J. L. 1990. Moisture loss from fruits and vegetables. Postharvest news and information, vol. 1, 1990, no. 3, p. 195-199.

\section{Contact address:}

prof. Ing. Magdaléna Valšíková, PhD., SUA in Nitra, Horticulture and Landscape Engineering Faculty, Department of Vegetables-Production, Tr. Andreja Hlinku 2, 94976 Nitra, Slovak Republic, e-mail: Magdalena.Valsikova@uniag.sk, phone: +42137641 4226 